\title{
AT THE CROSSROAD OF INTERNAL AND EXTERNAL MIGRATION: CONFLICT OF INTERESTS IN KUMKAPI
}

\author{
Ayşe Gür Geden \\ Postgraduate Student, King's College London \\ ayse.geden@gmail.com
}

\begin{abstract}
This study explores the conflict of interests in Istanbul's Kumkapi district between the Kurdish migrants from Eastern/South Eastern Anatolia and the African asylum seekers. While the survey with the Kurdish citizens reveal the assumptions and attitudes about the African asylum seekers in the area, in-depth interviews conducted with the Africans reveal their ideas about the locals and specific difficulties faced as black people in Turkey. The analysis of Kumkapi research shows frequent examples of xeno-racism (a peculiar combination of racism and xenophobia) as a result of the conflict. Therefore, the article aims to portray the internal migrants residing at Kumkapi area both as victims and perpetrators, while expressing their complaints and reactions. Regarding the increasing number of asylum seekers and refugees in Turkey, in order to prevent the problems spread, permanent solutions will be offered and discussed.
\end{abstract}

Keywords: Internal migration, international migration, illegal migration, asylum seekers, Africa, Xeno-racism, Turkey. 


\section{İ̧ VE DIŞ GÖÇ BAĞLAMINDA KUMKAPI'DA ÇIKAR ÇATIŞMASI}

\section{Özet}

Bu çalışma, İstanbul'un Kumkapı semtinde ikamet eden Afrikalı sığınmacılar ve iç göçle Doğu ve Güneydoğu Anadolu'dan gelerek bu bölgeye yerleşen Kürt bölge sakinleri arasındaki çıkar çatışmasını ele almaktadır. Kumkapı'da Kürt vatandaşlar ile gerçekleştirilen görüşmelerde hedeflenen, bölgede ikamet eden Afrikalı gruplara dair fikir ve yargıları açığa çıkarmak iken; Afrikalı görüşmeciler ile yapılan mülakat çalışmalarında amaçlanan, Türkiye'de siyahiler olarak karşılaştıkları problemleri ve bu grubun bölge sakinlerine dair fikirlerinin belirlenmesidir. Xeno-racism (yabancı düşmanlığı ve ırkçılığın sentezi) örneklerine sıkça rastlanan Kumkapı'ya ilişkin analizlerde, iç göç ile bölgeye yerleşenlerin menfi tutumları yanı sıra mağduriyetleri, şikâyet ve tepkileri de dile getirilecek; artan göçmen nüfusu göz önünde bulundurularak söz konusu çatışmaların Türkiye geneline yayılması intimaline karşın kalıcı çözüm yolları tartışılacaktır.

Anahtar Kelimeler: İç Göç, Uluslararası Göç, Yasadışı Göç, Sığınmacı, Afrika, Xeno-Racism, Türkiye.

\section{GíRiş}

Türkiye, coğrafi ve stratejik konumu nedeniyle göç yolları üzerinde bulunan bir bölgeye dahil; ayrıca, dışarıdan gelen nüfus hareketlerinin yanı sıra, kendi içinde çeşitli göç hareketlerine de şahitlik etmiş bir ülkedir. Dolayısıyla, birçok kültürü, geleneği, dili, dini, ırkı ve rengi barındıran bu coğrafya, göç deneyimini bir zenginliğe dönüştürebilmeyi başarmıştır. Fakat içinde bulunduğumuz yüzyılda, göç hareketlerinin yoğunlaşması, şekil ve amaç değiştirmesi, Türkiye'nin artık hem bir transit hem de hedef ülke haline gelmesine yol açmış; ülkeye önemli sorumluluklar yüklerken, beraberinde ciddi sorunlar da ortaya çıkarmıştır. Avrupa Birliği (AB) üyesi devletlerin "Kale Avrupası" inşası noktasındaki ısrarları, sıkı tedbirleri ve koruyucu tutumları, üyelik süreci devam eden Türkiye'nin göç politikalarını şekillendiren bir unsur olmuş ve Türkiye Cumhuriyeti yöneticilerinin omuzlarına ağır bir yük bindirmiştir. Söz konusu sorunların çözümünü kendi içinde aramak durumunda kalan Türkiye, daha etkili ve hızlı sonuçlar alabilmek için, sağlam ve gerçekçi politikalar üretmek maksadıyla, sokaktaki realitelerin ve sorunların farkına varmak durumundadır. Zorunlu göç de dâhil olmak üzere, iç göç ile Doğu ve Güneydoğu Anadolu bölgeleri illerinden İstanbul, Ankara, Bursa, İzmir gibi büyük kentlere göç eden bireylerin problemleri dahi tam anlamıyla çözüme kavuşturulamamışken; dış göç ile onlarca farklı ülkeden Türkiye'ye akın eden göçmenlerin yine büyük şehirlerde bir arada yaşamak durumunda kaldıkları iç göçmenler ile çıkar çatışmaları, bu bağlamda önemli bir sorun teşkil etmektedir. Bu gruplar içinde en görünür olan ve nüfus bakımından önemli rakamlara ulaşan Afrikalı sığınmacı grubunu incelemek bu bakımdan elzemdir.

\section{TÜRKIYE VE GÖÇ}

\subsection{Türkiye'ye Yönelik Düzensiz ve Yasadışı Göç}

Türkiye'ye yönelik göç, ulus-devletin inşa edilme süreci olan Cumhuriyet'in ilk yıllarında, etnik anlamda Türk ve Müslümanlardan oluşmuştur. Bu dönemlerin aksine, son yıllarda farklı etnik ve dini gruplardan milletlerin değişik amaçlar ile Türkiye'ye göç ettiği gözlemlenmektedir (İçduygu ve Yükseker, 2012). Eskiden göçmen gönderen bir devlet olan Türkiye, son 20 yılda göçmenlerin hedefi haline gelen ve transit olarak (başka bir ülkeye geçiş maksatı) kullanılan bir alana dönüşmüştür. Stratejik konumu nedeniyle birçok göç rotasının kesiştiği bir noktada bulunan Türkiye, 1980'lerden itibaren Orta Doğu, Asya, Doğu Avrupa ve Afrika'dan sürekli göç almakta; bilhassa göçmenlerin Türkiye'ye insan kaçakçılığı ile getirilmesi ya da çıkarılması nedeniyle mesele güvenlik ve suç söylemleri üzerinden değerlendirilmektedir. Türkiye'nin göç anlamında bu denli rağbet görmesi, problemli bir coğrafyanın tam ortasında yer almasından kaynaklanmaktadır. Soğuk Savaş sonrası dönemde yaklaşık 2-3 milyon Iraklı Kürt ve Şii'nin Saddam Hüseyin'in katliam saldırıları sonucu Türkiye sınırına dayanması, etnik temizlik nedeniyle evlerini terk eden 2,5 milyon eski Yugoslav vatandaşının akınına uğraması, klanlar arası savaştaki çatışmalardan kaçan ve kıtlık sebebiyle yerinden edilen Somalili sığınmacı nüfusu, İran'daki Devrim ve Afganistan'daki savaş nedeniyle gerçekleşen göçler, yine Türkiye'nin merkezinde bulunduğu bölgedeki sıkıntıların bir sonucudur (Loescher, 1993). Böylesine problemli bir coğrafyada nispeten istikrarlı nadir ülkelerden biri ve göç yolları üzerinde Avrupa'ya geçişin en kolay olduğu noktalardan olması nedeniyle Türkiye hem hedef hem de transit ülke haline gelmiştir (Biehl, 2008). Bu sebeple Türkiye'de 2000 yılından beri her sene 200.000 'den fazla göçmen kaydedildiği iddia edilmektedir (Çelebi et.al., 2011).

Bu bağlamda, çalışmanın odak noktası olan geçiş/transit göç ise, Türkiye'nin Batı sınırlarından Avrupa'ya geçmeyi hedefleyen ve bu yolculukta planlı ya da plansız biçimde Türkiye'ye gelmiş olan Afganistan, Bangladeş, İran, Irak, Pakistan, Somali, Suriye uyruklu vatandaşların gerçekleştirdiği göç türüdür. Bilhassa 
İran ve Suriye sınırlarından geçiş yapan bu transit göçmenler, insan kaçakçılı̆ı ağları sayesinde, Ege kıyılarından deniz ya da kara yoluyla (çoğunlukla Meriç Nehri üzerinden) Yunanistan'a geçmeyi amaçlamaktadırlar (İçduygu ve Yükseker, 2012). 1951 tarihli Cenevre Sözleşmesi'nde Kongo, Madagaskar ve Monako'nun yanı sıra, mültecilere yönelik "coğrafi kısıtlama" şartı getiren ülkelerden biri olan Türkiye, söz konusu göçmenleri Avrupa ülkeleri dışından geldikleri için anlaşma gereği mülteci statüsü verememekte; bu kimseler yasal olarak ancak 'sığınmacı' statüsüne başvurabilmektedirler. BMMYK "sığınma" kavramını şu şekilde açıklamaktadır:

"Sığınma" uluslararası hukukta tanımlanmamıştır; fakat bir ülkenin, topraklarında bulunan mültecilere sağladığı korumanın tümü için genel bir terim haline gelmiştir. Sığınma, en azından başka bir ülkede çözüm bulunana kadar, ev sahibi ülkede barınma imkânı sağlanması şeklinde, geçici bir süre için, temel koruma sağlanması anlamına gelmektedir (Jastram ve Achiron, 2001: 15).

Mültecilerden farklı olarak "sığınmacı", mülteci statüsü almaya yönelik başvurusu henüz karara bağlanmamış, ya da henüz başvuru yapmamış kişileri tanımlamak için de kullanııı. Sığınmacılar sosyal yardım ve konut bazında ciddi zorlukların beraberinde, engel koyucu bir bürokrasi ile de mücadele etmek durumundadır. İş ortamındaki temel statü eşitsizliği ise, sans papier olarak da bilinen ve devlet tarafından henüz tanınmayan sığınmacı grubunu -saha araştırmasının da ortaya çıkardığı üzere- mağdur etmektedir (Lloyd, 2003).

\subsection{Transit Ülke Olarak Türkiye}

Transit göç, Batı Avrupa ülkelerine gitmek isteyen, fakat artan sınır kontrolleri, ileri teknoloji izleme cihazları ve diğer teknolojik teçhizatların konuşlandırılması nedeniyle direkt hedef ülkeye geçiş yapamayan (özellikle Afrika ve Asya kökenli) insanların, Avrupa'ya komşu ülkelere gidip oradan hedeflerine ulaşmaları anlamına gelir (Amnesty International, 2014; Şaul, 2013; Düvell, 2010).

Türkiye'nin bir geçiş ülkesi haline gelmesinin nedenleri arasında Asya, Avrupa ve Afrika kıtalarının kesiştiği bir coğrafi bölgede yer alması, AB'nin güneydoğusuna hem deniz hem de kara sınırı olması, Doğu ve Güneydoğu Anadolu Bölgelerinde geçmişte yaşanan yoğun yasadışı göçler bulunmaktadır (İçduygu ve Yükseker, 2012: 443). Transit göçün başat unsuru olan kaçakçılar sayesinde Afgan, Pakistan, Bangladeş uyruklu Asya kökenli, Irak, Suriye, Filistin gibi Orta Doğu ve Somali gibi Afrika menşeli göçmenlerin Avrupa'ya geçişlerinde Yunanistan esas giriş kapısı olmakla beraber, Türkiye de 1970'ten beri ana geçiş ülkesi rolünü üstlenmektedir (Frenzen, 2013; l̇çduygu ve Yükseker, 2012). Hukuka uygun muamele ilkesine riayet edilmeden yapılan geri göndermeler ve geri kabul anlaşmaları bağlamında gerçekleştirilen sınır dışı işlemleri sebebiyle, Avrupa'ya güvenli ve daha iyi bir hayat hayaliyle yola çıkan çok sayıda kişi, $A B$ çevresindeki ülkelerde sıkışıp kalmaktadır. Dolaysıyla, geldikleri yolu izleyerek ülkelerine dönebilecek maddi imkanları ya da resmi belgeleri olmayan göçmenler Libya, Fas ve Türkiye gibi ülkelerde yasadışı olarak, yahut transferleri için üçüncü ülke bulunana dek yokluk ve sömürü içinde çalışarak hayata tutunma çabası göstermektedirler (Amnesty International, 2014). Tüm bu transit göçler, sonuçları itibariyle Türkiye'nin (bilhassa $A B$ ile olan) dış politikasını da etkilemekte ve şekillendirmektedir. Türkiye Devleti göçü bir dış ilişkiler meselesi olarak görmeye başlamış, dolayısıyla göçe dair kaygılar dış politikanın rotasını belirleyici bir unsur haline gelmiştir (Tolay, 2012).

\subsection{Türkiye - Afrika İlişkileri ve Göç}

Kuzey Afrika'da yüzyıllar boyunca egemen bir güç olan Osmanlı Devleti'nin esas mirasçısı Türkiye, AB ile entegrasyon sürecinde uzun süredir yaşadığı hayal kırıklığı nedeniyle yeni pazarlar ve liderlik arayışıyla, son zamanlarda Afrika kıtasına ekonomik ve politik anlamda daha yakın bir ilgi göstermeye başlamıştır (Özkan ve Akgün, 2010). 1998'de Afrika Eylem Planı'nın kabulü Türkiye'nin Afrika'ya olan ilgisini giderek artırmış, 2005 sonrasında ise bu ilgi zirveye ulaşmıştır. Aynı yıl Afrika Birliği'nde (AU) "gözlemci" statüsünü kazanan Türkiye, 2008 yılında AU tarafından stratejik partner ilan edilmiştir. Söz konusu ilişkiler ekonomik açıdan olumlu sonuç vermiş, Afrika ile 2003'te 5.4 milyar dolar olan ticaret hacmi, 2008'de üç kat artarak 16 milyar doları geçmiştir (ibid). Türkiye İşadamları ve Sanayiciler Konfederasyonu (TUSKON) aracılığıyla da dış ticaret fırsatları yakalayan Türkiye, insani yardım kuruluşları ve STK'lar ile de Afrika'da aktif konumunu sürdürmektedir. Araştırmada yer alan Afrikalı görüşmecilerin, Türkiye'ye dair göç öncesi müspet algılarını yine bu gelişmelerin şekillendirdiği ortaya çıkmaktadır.

\subsection{Uluslararası Göç ve İç Göç Odağında İstanbul}

\subsection{1 İstanbul'a Yönelik Iç Göçler ve Özellikleri}

1960'larda, sanayinin tarıma oranla daha hızlı büyümesi ve kentsel hizmet sektörünün gelişmesi ile iç göç ivme kazanmış, 1955 yılında İstanbul'da 50.000 olan gecekondu sayısı 1960'ta 240.000'e yükselmiştir. 
Yaşam tarzından sosyal ilişkilere dek pek çok sıkıntı ile karşılaşan göçmenler, cemaatleşme mekanizmasına sıkıca sarılmış, ayrıca (araştırma dâhilinde Kürt görüşmecilerin de ifade ettiği üzere) akrabalık-hemşerilik ilişkilerini yoğun biçimde kullanmaya çalışmışlardır (Kaygalak, 2009). 1980'lerde uygulanan neoliberal ekonomi politikalarının sonucu olarak emek piyasasında taşeronlaşma, eve iş verme, parça başı iş, sözleşmeli ve mevsimlik iş̧̧ilik gibi uygulamaların önemi artmış; dolayısıyla bir yandan çalışanların ücretleri düşmüş, diğer yandan ise göç edenler adına örgütsüz çalışma kanalları ve kayıt dışı işler çoğalmıştır. Aynı dönemde, kentlerde farklılaşma ve kutuplaşma ciddi anlamda ivme kazanırken, şehirlerde birbirinden oldukça uzak ve farklı gruplar ortaya çıkmıştır (ibid).

12 Eylül askeri rejimi ertesinde patlak veren silahlı PKK hareketi ve 1987'de ilan edilen Olağanüstü Hal (OHAL) nedeniyle birçok kırsal yerleşim yerinin boşaltılması ve insanların göç etmek zorunda kalması yeni sorunlara yol açmıştır (TESEV, 2008) Örneğin, kentte artan kapkaç, soygun ve bir dizi asayiş sorunu ile göçmenlerin bağlantılı olduğu kanaatinin hala hakim olması (Kaya, 2009) bilhassa genç göçmenleri hedef haline getirmekte, zaten travma sonrası stres bozukluğu yaşayan bu bireyleri genel kent nüfusuna göre daha fazla depresyon, yoğun kaygı ve umutsuzluğa itmektedir (TESEV, 2008). Söz konusu menfi imaj nedeniyle iş bulmakta sıkıntı çeken göçmenler, gerek küçük imalathanelerde, gerekse fabrikalarda akrabalık, mezhep ve hemşerilik kıstaslarıyla karşı karşıya kalmaktadırlar (Duben ve Şimşek, 2002). Bunun bir sonucu olarak, hem vasıfsız Kürtlerin daha ucuz bir emek olmaları, hem de belli iş kollarında üstünlüğe sahip olup etnik benzerlerini kollamaları nedeniyle günümüzde birtakım sektörlerde Kürt nüfus ağırlıktadır (Duman, 2013).

\subsection{2 İstanbul'da Afrikalı Sığınmacı Profili}

Umberto Eco (2012) içeriden göç olgusunda göçmenlerin, göç ettikleri yerin kültürünü köklü biçimde değiştirirken; dışarıdan göçte göçmenlerin var olan kültürle uyum sağladıklarını ifade eder. Kumkapı örneğinde görüleceği üzere, iç göçle gelen Kürt nüfusun adet ve yaşam tarzlarını şehirde de devam ettirmeye çalışmaları; Afrikalıların ise dikkat çekmemek için mümkün olduğunca kültüre ayak uydurmaya meyilli olmaları, Eco'yu doğrular niteliktedir. Genellikle düşük sosyal statülü belli iş kollarında yoğunlaşan iç ve dış göçmenler, mekân tercihlerini de buna göre yapmaktadırlar (Castles ve Miller, 2008). Dolayısıyla Afrikalı sığınmacılar İstanbul'un tarihi kent merkezlerini mesken tutmaktadırlar. Bu durumun temel nedeni, daha önce İstanbul'un tarihi ve kültür merkezi olan bölgelerin (sanayinin desantralizasyonu gibi) iktisadi yapılarındaki değişimlere ve nüfus hareketlerine bağlı olarak boşalması, dolayısıyla göçmenlere ucuz konut ve enformel işlere yakınlık gibi olanaklar sunmasıdır (Adıgüzel, 2012). Bilhassa Tarlabaşı ve Kumkapı gibi kentin çöküntü bölgelerini mesken tutan Afrikalılar köken, kültür, göç sebepleri, göç biçimleri, hayatta kalma stratejileri, gelirleri ve sosyal ağları bakımından önemli farklııklar gösterirler (Brewer ve Yükseker, 2006). Afrikalı göçmenler arasındaki en kalabalık grupları Senegal, Nijerya, Somali, Kamerun ve Kongo uyruklular oluşturmaktadır. Kiliseler, dernekler ve STK'lardan yardım alabilen sığınmacılar, tezgâhtarlıktan seyyar satıcılığa, hamallıktan fotomodelliğe uzanan geniş bir yelpazede istihdam edilebilmektedirler (Şaul, 2013). Erkek nüfusunun büyük bir kısmı ve ana dili Fransızca olanlar daha çok Tarlabaşı'nda ikamet ederken, Kumkapı'da bekârların yanı sıra aileler Doğu Afrikalılar, İngilizce ve Arapça konuşanlar ağırlıktadır (Danış, 2005). Türkiye'nin herhangi bir yerinde ya da bir uydu kentte kalmaktansa, daha az strese maruz kalmak amacıyla, Kumkapı ve Tarlabaşı'nda kendi vatandaşlarının yanına yerleşerek, bu bölgeleri "Afrika banliyösü" haline getiren sığınmacılar (Doğan, 2011) diğer bölgelerde kendilerini tehlikelere daha açık ve savunmasız hissetmektedirler.

\section{METODOLOJi}

\subsection{Amaç ve Kapsam}

Çalışma Kumkapı'da ikamet eden Afrikalı sığınmacılara ve Kürt vatandaşlara odaklanmaktadır. Çalışmanın amacı, grupların birbirlerine karşı tutumlarını ve algılarını tespit etmek, bunların sebeplerine değinmek, tarafların ortak, benzer ve farklı deneyimlerini analiz etmek, bulguları değerlendirerek geleceğe yönelik tahminler ve çözüm önerileri sunmaktır.

\section{2 Çalışma Grubu ve Veri Toplama Aracı}

Araştırmanın örneklemini Afrika'dan göç ederek Türkiye'ye yasal ya da yasadışı giriş yapmış Kumkapı'da ikamet etmekte olanlar ve Kumkapı'ya iç göçle gelen Kürt vatandaşlar oluşturmaktadır. Kürt vatandaşlar için rastlantısal örnekleme (probability sampling) kullanııırken, Afrikalı sığınmacılar için amaçlı örnekleme (nonprobability sampling) kapsamında kartopu tekniği kullanıımıştır.

Saha araştırması öncesinde, Kumkapı bölgesinde birçok kez gözlemlerde bulunulmuş, birçok Afrikalı sığınmacı ve Kürt vatandaş ile kısa enformel sohbetler gerçekleştirilmiş; bölge esnafı ve muhtarları ile görüşülmüş, araştırmada kullanıımak üzere notlar alınmış; görüşmeci sayısı, süresi, kısıtlamalar, engeller ve 
çözümlere dair genel bir çerçeve çizilmiştir. 20 kişi olarak belirlenen Afrikalı grup ile yürütülen araştırmada daha az sayıda kişi ile daha fazla görüşme mesaisi harcanarak veri elde edilmesi hedeflenmiş, bu nedenle derinlemesine mülakat ve çoklu mülakat teknikleri uygulanmıştır. Kürt vatandaşlar ile görüşmelerde açık, yarı kapalı ve kapalı uçlu sorulardan oluşan anket (survey) uygulanmıştır.

\subsection{Veri Analizi ve Araştırmanın Sınırlılıkları}

Araştırmacının kontrolü dışındaki sebeplerden ötürü (görüşmecilerin isteksizliği, zaman kısıtlaması ve cevapların yüzeyselliği) nedeniyle Kürt görüşmecilerden ancak 20 verimli anket sonucu elde edilmiştir. Elde edilen veriler SPSS ile analiz edilmiştir. Bu bağlamda, anket katılımcı sayısının düşük olması bir kısıtlama olarak zikredilebilir. Afrikalı sığınmacıların verileri ise araştırma soruları ve kavramsal çerçeve bağlamında oluşturulan temalar altında düzenlenmiştir. Dolayısıyla betimsel analiz yöntemi ile değerlendirilen sığınmacı verileri Kürt görüşmecilerin cevapları ile karşılaştııılarak yeniden kategorizasyon yapılmış ve bulgular şekillenmiştir. Araştırmanın önemli bir diğer kısıtlaması ise kadın görüşsmeci sayısının düşük olmasıdır. Afrikalı kadınların sokaklarda sıklıkla sözlü ve zaman zaman da fiziksel tacize uğruyor olmaları, çalışanlar hariç (bilhassa Somalili) kadınların genelde evlerinden çıkmamayı tercih etmeleri sebebiyle kadınlarla evlerinde ya da aile veya erkek arkadaşları eşliğinde görüşülmüştür. Kürt kadınları ise ev içi sorumlulukları ve mahremiyet nedeniyle genelde görüşmekten kaçınmışlardır.

\section{BULGULAR}

\subsection{Afrikalı ve Kürt Görüşmecilerin Birbirlerine Dair Algıları}

\subsubsection{Sığınmacı Algısı}

Kumkapı'da ikamet eden Kürt vatandaşlara yöneltilen "Sizce sığınmacı kime denir?" sorusuna "Savaştan kaçan insanlar" ve "Ülkesinden çıkmak zorunda kalan" cevaplarının yanı sıra, "Kürtlere ve Kürtlerin yaşadıklarına benzer şeyler yasayanlara denir" yanıtları da alınmıştır. Bu ifadeler, zorunlu göç ile memleketini terk ederek İstanbul'a yerleşmiş olan Kürt nüfusun bir kısmının, yabancı göçmenler ile benzerliklerinin bilincinde olduklarının ve kendi serüvenleriyle özdeşleştirdiklerinin bir göstergesi olarak yorumlanabilir. Bununla beraber, "(sığınmacı) benim as/ında, fuhuş yapan değil. Onların maddi durumu benimkinden iyi" ifadesi de menfi sığınmacı imajına dair ipuçları sunmaktadır.

\subsubsection{Gruplar Arası Illetişim}

\%90'ı yabancı göçmenler ile bizzat iletişime geçen Kürt görüşmeciler, \%70 oranında Afrikalı (bilhassa Somalili) sığınmacılar ile dirsek temasında bulunmuşlardır. Ayrıca, Kürt görüşmecilerin \%60'ının Afrikalı gruplarla her gün muhatap olduğu bilinirken; bu iletişimin \%55'inin işyerinde, \%35'inin ise sokakta gerçekleştiği ve komşuluk iliş̧isine dayandığı, \%10'unun ise Afrikalılar ile camide karşılaştıkları ifade edilmiştir. Afrikalı sığınmacılar ise sosyal birlikteliklerini, "beyazlar" dedikleri Türkler'in menfi tutumlarından ötürü Kumkapı'dan ziyade yine kendileri gibi Afrikalılar ile yaşadıklarını örneğin şu ve benzeri ifadeler ile belirtmişlerdir:

Türkler pek arkadaş olmaz bizle. Yani iş yerinde birlikte olabiliriz ama orada biter. Arkadaşın olsa birlikte takılırsın. Birbirinize gidip gelirsin, bir şeyler paylaşırsınız. Afrikalı arkadaşlarımın da Türklerle yakın arkadaş olduğunu görmedim, belki sadece iş arkadaşları. Ama o kadar. (Ahmad, 28, Gambia)

\subsubsection{Sığınmacı Algısında Din Faktörü}

Afrikalı gruplar içinde bilhassa Somalililere sempati besleyen Kürt görüşmeciler, bu grupla ile iyi anlaştıklarını ve problem yaşamadıklarını belirtmişlerdir. Bir görüşmeci "Somaliliye dükkân teslim ederim, ama Mısırlıya etmem mesela" derken; diğer bir görüşmeci ise "Asayişi bozan da var, kendi halinde olan da. Somalililer istedikleri kadar gelsinler" diye eklemiştir. Dolayısıyla Müslümanların daha iyi insanlar oldukları, diğerlerinin ise genelde suç işledikleri algısı hâkimdir. Müslüman Afrikalıların şu ifadeleri söz konusu algının avantajına işaret etmektedir:

Burada arkadaşlarla karşılaştı̆ı̆ız zaman bazen soruyorlar Müslüman mısın diye ben de Elhamdülillah Müslümanım deyince hemen el sıkışıyorlar. Bir bağ gibi yani. (Yasa, 26, Mali)

Müslüman olmaktan çok gurur duyuyorum. Türklerle tek ortak olabildiğimiz nokta orası. Camide aynı yerde duruyoruz ve birkaç söz paylaşıyoruz. (Kanagnte, 32, Fildişi Sahilleri)

\subsubsection{Afrikalı Kadınlara Dair Önyargılar ve Stereotipler}

Afrikalı kadınlar genellikle fuhuş ile ilişkilendirilmekte, erkeklerin "kötü işlere meylinin artması ve aile 
ortamında düzensizlik yaratmaları" ile itham edilmektedirler. Afrikalı kadınlar ise Kumkapı ve civarında maruz kaldıkları cinsel taciz ve tecavüz vakalarından utanarak ve çekinerek bahsetmektedirler:

Tabii ki beyazlar ve Afrikalılar kesinlikle aynı değil. Onlara en azından saygı gösteriyorlar. Biz ise bir yerde çalışmak, iş bulmak istediğimizde illa ki bunun bedelini ödemek zorundayız. Hepsinin kafasında Afrikalı kadınları hayat kadını görme fikri var. Bazen yolda yürürken arkadan bir amca yaklaşıyor, "seks, seks kaç para" diye soruyor. (Emina, 30, Kamerun)

(Kumkapılıların) Kimileri hepsinin fahişe olduğunu düşünüyor. (Neden böyle düşündüklerini) Bilmiyorum, belki de kimisinin gerçekten bu işi yaptığını gördükleri için. Paketteki bir bozuk patates yüzünden hepsi çürüyor yani. Ben böyle düşünüyorum (Ahmad, 28, Gambia)

"Fuhuş" suçlamaları karşısında Afrikalı kadın görüşmecilerin dile getirdikleri hususlar, söz konusu algının temelinde kendilerine dair önyargılara ve stereotipleştirmeye, bunun sonucu olarak da ciddi bir mağduriyete işaret etmektedir.

\section{2 Çıkar Çatışması ve Xeno-racism}

Esses et.al.'a (1998) göre, rekabet algısı çatışmaya ve gruplar arası düşmanlığa itici bir faktördür. Çatışmalar bireylerin kişisel çıkarları değil, grupların kolektif çıkarları ve bu çıkarların muhafazası sebebiyle ortaya çıkmaktadır. Dolayısıyla, ucuz işgücü sağlayan Afrikalı sığınmacıların varlığı, zaten kısıtlı olan iş imkânlarının ellerinden alınacağı endişesi duyan Kumkapı'daki Kürt vatandaşları öfkelendirmektedir. Ayrıca sığınmacılar nedeniyle Kumkapı'da ev kiralarının artması, çoğu zaten yoksul olan ailelerin kira giderlerini etkilemektedir. Söz konusu durum, salt ırkçı beyaz/siyah dikotomilerinden bağımsız olarak "öteki”ni, dış görünüşü (beyaz dahi olsa), dini, kültürel ve etnik grup aidiyeti nedeniyle marjinalleştirmek, tehdit etmek, aşağılamak ve kişiliksizleştirmek anlamına gelen xeno-racism uygulamalarına yol açmaktadır (Every ve Augoustinos, 2007). Agier'e (2008) göre, toplumun marjinal mensupları olarak göçmenler, kir ve pislikle özdeşleştirilmekte, toplumun biyolojik, ahlaki ve kimlik bazında saflığını bozan maddeler olarak görülmektedirler (ibid: 32-40). Kürt görüşmecilerin \%60'ının bizzat olumsuz bir deneyim yaşamaması ya da menfi bir duruma şahit olmamasına rağmen, Afrikalıları ahlaksızıkla, suç oranını artırmakla ve asayişi bozmakla itham etmeleri xeno-racist tutumlara örnek gösterilebilir.

Her iki grubun göç deneyimleri bakımından ne denli benzeştikleri düşünülürse, ortaya ironik ve trajik bir tablo çıkmaktadır. Kürt görüşmecilerin Afrikalı komşularının geçmekte olduğu safhaları yaşamış ve hala da yaşıyor olmaları, ifadelerindeki benzerlikte bariz hale gelmiştir. Ayrıca, Kürtlerin dayanışma ve ayakta kalma çabaları Afrikalılarda da gözlemlenmektedir. Yıllardır fakirlik, sosyal dışlanma ve tecritle karşı karşıya kalan Kürt göçmenlerin şehirli yoksulları, şimdi de gittikçe artan uyuşturucu kullanımı ve yasadışı aktiviteler gibi problemler ile baş etmek durumundadır (Çelik, 2005). Bu anlamda Afrikalı sığınmacıların durumunun da çok farklı olmadığı iddia edilebilir. Dolayısıyla, xeno-racist tutumların bilhassa daha bilinçli olması beklenen ve benzer problemlerle karşılaşan gençler tarafından uygulanıyor olması ayrıca şaşırıcıdır:

Gençler genelde daha tenkitçi ve alaycı. Bazen arkadaş canlısı gibi davranıp, kandırmaya çalışıyorlar, aslında arkadaşlık değildir niyetleri. ... Irkçıı̆ı ve bu hakaretleri kimse yok edemez bir ülkeden. Bu yaşam şekli olmuş, yıllardır süre gelen bir şey bu. ... Yani bununla baş etmek çok zor. ... Birçok insan okula gidemiyor, bilinçli değiller, haberleri dinlemiyor, gazete okumuyor. Bu insanlarla konuşmak, onları etkilemek çok zor. ... Bilmiyorum doğru mu ama herkes Kürtlerin en kötü olduğunu söylüyor. Çünkü bizi çalıştırıyorlar ve ödemeleri yapmıyorlar. Bu fabrikaların çoğu onların elinde sanırım. Eğer ırkçııktan bahsediyorsak bence onlar en kötüleri.(Ahmad, 28, Gambia)

Kumkapı'da enformel sektörde istihdam edilen Afrikalılara yönelik -yasadışı olmanın kapı araladığı- taciz, şiddet ve tecavüz vakalarına hemen yanı başlarında bulunan Emniyet Müdürlügü’nün göz yumması ve herhangi bir müdahalede bulunmaması ise, söz konusu saldırıları teşvik etmektedir. Polise ve adalete güvenmeyen Afrikalı sığınmacıların ifadeleri dikkat çekicidir:

Problemlerden neden kaçıyoruz çünkü siyahla beyaz arasına bir problem olunca hemen alıp polise götürüyorlar. Kimin suçlu olduğuna bakmadan, sormadan soruşturmadan hemen bizi cezaevine götürüyorlar. (Yani, 33, Mali)

Kendilerini ırkçı addetmeyen Kürt görüşmeciler bir yandan Afrika'dan gelen göçmenlere insanlık namına, intiyaç sahibi oldukları için ya da Müslüman kimliklerinden ötürü yardım edilmesi gerektiğinden ve misafirperverliklerinden bahsederken, diğer yandan devletin önceliğinin kendi vatandaşı olması gerektiğini 
vurgulamakta ve Afrikalı sığınmacılara yapılan yardımları tasvip etmediklerini dile getirmektedirler. İlginç olan bir diğer husus ise, İslam ortak paydasında buluştuğunu iddia eden -görüşmecilerin temsil ettiği- bölge sakinlerinin, sırf kendileri gibi hareket etmiyorlar diye Afrikalılar ile camilerde dahi, kültür farkı nedeniyle yer yer kavgaya varan çatışma yaşamalarıdır. Dolayısıyla, kültür ve tutumların farklı olması direkt ırkçılık kapsamına girmese dahi, xeno-racism'i çağrıştırmaktadır.

Afrikalı sığınmacıların da dikkat çektiği üzere, Avrupa'da yükselen ırkçılık ve yabancı düşmanlığı nedeniyle Türkiye'yi tercih eden siyahilerin Kumkapı'da benzer tutumlara rastlamaları, söz konusu xeno-racist algının köklü bir zihniyet değişimi olmaksızın çözülmesi mümkün görünmeyen bir problem olduğuna işaret etmektedir. Bu noktada en önemli sorun, gittikçe artan çok renkli, çok dilli, çok kültürlü ve çok ırklı uluslararası göçmen potansiyeli ile Türkiye'nin, göç kapsamında mevcut sorunlara nasıl çözüm bulacağı ve pusuda bekleyen problemlerle ne tür önlemler alacağıdır.

\section{SONUÇ VE ÖNERILER}

Kürt vatandaşlar ve Afrikalı sığınmacıların anlatıları saldıılar, ırkçı tacizler ve suiistimaller ile gittikçe yükselen bir gerginliğe işaret etmektedir. Görüşmecilerin ifade ettiği üzere güvenlik güçlerinin bihaber olmadığı fakat göz yummayı tercih ettiği bu tür cezalandırımayan suçlar, çatışmaları körüklemekte ve suçluları ödüllendirmektedir. Türkiye, söz konusu xeno-racist saldırılar noktasında ivedilikle sosyal politikalar geliştirmek ve uygulamaya koymak durumundadır. Aksi takdirde, artan göçmen nüfusu ve yükselen tansiyon toplumsal barış ve refahı zedeleyerek, Türkiye'yi kontrol altına alınamayan bir kaosa sürükleyecektir.

Devletler ve kurumlar düzeyinde bakıldığında, göçmenlerin iş piyasasına erişimlerinin sağlanması ve bu noktada halkı da mağdur etmeyecek biçimde koşulların iyileştirilmesi gerekmektedir (Amnesty International, 2014). Toplum düzeyinde ise sığınmacılara dair bilinç uyandırılması maksadıyla devletin birtakım kampanyalar yürütmesi, mevcut algıların yol açtığı yabancı düşmanlığı ve ırkçılık sorunlarına yönelik farkındalığı artırıcı projeler düzenlenmesi elzemdir. Bu projelerin yalnızca topluma yönelik kalmaması, başta polis memurları olmak üzere sığınmacılar ile temasa geçen bütün memurların bilinçlendirilmesi gerekmektedir. Bilhassa xeno-racism meselesine eğilerek, algıları şekillendirici uygulamalar ile menfi eğilimdeki tutum ve yargıların değişmesine çalışılmalıdır (Handmaker ve Parsley, 2001). Bu bağlamda, "fahişe" olarak görülen Afrikalı kadınlar için bilhassa projeler düzenlenerek önyargılar bertaraf edilmeli, işyeri ve sokaktaki mağduriyetleri giderilmelidir. Devletin polis ve diğer memurları aracılığı ile gerçekleştireceği düzenli kontroller ile, cinsel suiistimal ve saldırıların önüne geçilmeli, bu yönde hem çalışan hem de işverenlerden istihbarat alınmalıdır. Göçmenlerin taciz vakaları durumunda polise gitmelerini kolaylaştıracak düzenlemeler bu anlamda ivedilikle oluşturulmalı, "T.C. vatandaşı her daim haklıdır" algısı ortadan kaldırılmalıdır. Tacizlerin azaltılması noktasında dikkat edilmesi gereken bir diğer husus ise, uydu kentlerin seçiminde ve bu kentlerdeki gözetim ve kontrollerde hassasiyet gösterilmesidir. Zaten kırılgan bir grup olan Afrikalı sığınmacıların, yabancılara alışkın olmayan veya önyargılı bir toplulukla baş başa bırakılması ya da izole edilmesi, deri renkleri, kıyafetleri, dilleri ve inançları nedeniyle oldukça görünür oldukları bir ortamda onları cezalandırmak ve tehlikenin ortasına atmak anlamına gelecektir (Schuster, 2003). Son olarak, bütün göçmen gruplara yönelik çalışmalar, Türkiye'nin göç rejimini etkileyen ulusal kimlik-etnik kimlik bağlamından çıkarılmalı; bu bireylerin aidiyetleri ve kimlikleri ne olursa olsun topluma entegrasyonlarını artırıcı eğitim ve kurslar sağlanmalı, danışmanlık ve istihdam aracılığı ile toplumdan dışlanmalarına engel olunmalıdır. Sivil toplum kuruluşları, dini kurumlar, dernek ve vakıflar aracılığı ile bu süreç hızlandırılabilir ve daha verimli sonuçlar alınabilir (Dedeoğlu ve Gökmen, 2011; Schuster, 2004).

\section{TEŞEKKÜR}

İstanbul Üniversitesi Bilimsel Araştırma Projeleri Birimi'ne, 36580 no'lu proje desteği ile saha çalışmam için sağladığı maddi katkıdan dolayı teşekkür ederim.

\section{KAYNAKÇA}

Adıgüzel, Y. (2012). Esenler'de Yaşamak, Memlekette Ölmek: Göç ve Kente Uyum Sürecinde Hemşehrilik. Murat Şentürk (Ed.), Göç, Kentleşme ve Aidiyet Ekseninde Esenler'i Anlamak içinde (s.185-222). İstanbul: Esenler Belediyesi Şehir Düşünce Merkezi Şehir Yayınları.

Agier, M. (2008). On The Margins of the World: The Refugee Experience Today. Cambridge, UK: Polity.

Amnesty International (2014).Kale Avrupası'nın İnsani Bedeli. (Çevrimiçi) http://www.amnesty.org/en/library/asset/EUR05/001/2014/tr/146bad2c-1183-4aee-a96ae15f8fc1ef7f/eur050012014tr.pdf . 10 Temmuz 2014. 
Biehl, K. (2008). Migration 'Securitization' and its Everyday Implications: an examination of Turkish asylum policy and practice (2009/1). European University Institute.

Brewer, K. T., \& Yükseker,H.D. (2006). A Survey on African Migrants and Asylum Seekers In Istanbul. Istanbul: Migration Research Program at Koç University.

Castles, S., \& Miller, M. J. (2008).Göçler Çağı: Modern Dünyada Uluslararası Göç Hareketleri. İstanbul: İstanbul Bilgi Üniversitesi.

Çelebi,Ö., Özçürümez ,S., \& Türkay,Ş. (2011).iltica, Uluslararası Göç ve Vatansızlık: Kuram, Gözlem ve Politika. Ankara: BMMYK.

Çelik, A. B. (2005). "I miss my village!": Forced Kurdish migrants in İstanbul and their representation in associations". New Perspectives on Turkey, (32), S.137-161.

Danış, D. (10 Eylül 2005). Bir Yiğit Gurbete Gitse. Bianet. (Çevrimiçi) http://www.bianet.org/bianet/toplum/66790-bir-yigit-gurbete-gitse. Erişim: 3 Ocak 2013

Dedeoğlu,S., \& Gökmen, C. E. (2011). Göç ve Sosyal Dışlanma: Turkiye'de Yabancı Göçmen Kadınlar. Ankara: Efil.

Doğan, İ. (21 Mart 2011). "Hedef Ülke Türkiye”. Aksiyon, Sayı: 850. (Çevrimiçi) http://www.aksiyon.com.tr/aksiyon/haber-28969-26-hedef-ulke-turkiye.html Erişim: 8 Ocak 2014

Duben, A., Şimşek,L. (2002). Kent, Aile, Tarih. İstanbul: İletişim.

Duman, B. (2013). "Yoğun Göç Almış Metropollerde Etniklik ve Öteki ile İlişki". Sosyoloji Dergisi, 3 (27).

Düvell, F. (2010). "Transit Migration: A Blurred and Politicized Concept". Population, Space and Place, (18).

Eco, U. (2012). Beş Ahlak Yazısı.İstanbul: Can Yayınları.

Esses, V.M., Jackson, L.M., Armstrong, T.L. (1998). "Intergroup Competition and Attitudes Toward Immigrants and Immigration: An Instrumental Model of Group Conflict”. Journal of Social Issues. Vol. $54(4)$

Every, D., Augoustinos, M. (2007). "Constructions of racism in the Australian parliamentary debates on asylum seekers". Discourse Society, 18(4).

Frenzen, N. (29 Ocak 2013). PACE Calls for Urgent Measures to Assist Greece and Turkey With Mounting Migratory Tensions in Eastern Mediterranean [Migrants at Sea Blog]. (Çevrimiçi) http://migrantsatsea.org/tag/frontex-joint-operation-poseidon-sea/ Erişim: 3 Nisan 2013.

Handmaker, J., \& Parsley, J. (2001). "Migration, Refugees, and Racism in South Africa”. Refuge, 20 (1).

İçduygu, A., Yükseker, D. (2012) Rethinking Transit Migration in Turkey: Reality and Re-Presentation in the Creation of A Migratory Phenomenon. Population, Space and Place,18(4).

Jastram, K., Achiron, M., Inter-Parliamentary Union., \& Office Of The United Nations High Commissioner For Refugees. (2001). Mültecilerin Korunması: Uluslararası Mülteci Hukuku Rehberi. Ankara: BMMYK.

Kaya, A. (2009). Türkiye'de Iç Göçler: Bütünleşme mi, Geri Dönüş mü? : İstanbul, Diyarbakır ve Mersin Örnekleri. İstanbul: İstanbul Bilgi Üniversitesi Yayınları.

Kaygalak, S. (2009). Kentin Mültecileri: Neoliberalizm Koşullarında Zorunlu Göç Ve Kentleşme. Ankara: Dipnot.

Lloyd, C. (2003). "Anti-Racism, Racism and Asylum-Seekers in France". Patterns of Prejudice, 37(3).

Loescher, G. (1993). Beyond Charity: International Cooperation and the Global Refugee Crisis. New York: Oxford University Press.

Özkan, M., Akgün, B. (2010). "Turkey's Opening to Africa”. Modern African Studies, 48(4).

Schuster, L. (2003). "Common Sense or Racism? The Treatment of Asylum-Seekers in Europe". Patterns of Prejudice, 37(3).

Schuster, L. (2004). "The Exclusion of Asylum Seekers in Europe". Centre on Migration, Policy and Society Working Paper (1).

Şaul, M. (2013). "Sahra Altı Afrika Ülkelerinden Türkiye'ye İş Göçü”. Ankara Üniversitesi SBF Dergisi, 68(1). 
TESEV Ülke İçinde Yerinden Edilme Sonrası Vatandaşlık Haklarının Yeniden Tesisi Ve Rehabilitasyon Araştırma Ve İzleme Grubu. (2008). Türkiye'de Ülke İçinde Yaşanan Yerinden Edilme Sorunu: Tespitler ve Çözüm Önerileri. TESEV

Tolay, J. (2012). Coming and Going: Migration and Changes in Turkish Foreign Policy. In Turkey and its Neighbors: Foreign Relations in Transition (pp.119-143). Boulder, Colo: Lynne Rienner Publishers. 